\title{
KEMAMPUAN GURU-GURU IPA SMP DALAM MENYUSUN PROPOSAL PENELITIAN TINDAKAN KELAS (PTK)
}

\author{
Oleh: \\ Tutut Nurita ${ }^{1}$, Martini ${ }^{2}$, Hasan Subekti ${ }^{3}$ \\ ${ }^{1,2,3}$ Prodi Pendidikan IPA FMIPA Unesa \\ tututnurita@unesa.ac.id
}

\begin{abstract}
Abstrak
Keputusan Menteri Pendayagunaan Aparatur Negara dan Reformasi Birokrasi Nomor 16/2009 tentang Jabatan Fungsional Guru dan Angka kreditnya salah satunya, diatur bahwa kegiatan guru harus meliputi unsur utama Pengembangan keprofesian berkelanjutan, yang meliputi: (1) pengembangan diri; (2) publikasi ilmiah; dan (3) karya inovatif. Dengan memperhatikan unsur-unsur kegiatan yang harus dipenuhi oleh guru di atas, di mana guru dituntut untuk bisa menghasilkan karya ilmiah (inovatif) dan mempublikasikannya, maka Tim Pelaksana PKM bermaksud untuk mengetahui kemampuan guru-guru IPA SMP di Kabupaten Jombang dalam menyusun proposal penelitian tindakan kelas. Metode dalam kegiatan PKM ini meliputi: memberi informasi tentang PTK dan workshop pendampingan penyusunan proposal PTK.
\end{abstract}

Kata Kunci: Proposal, Penelitian Tindakan Kelas, Workshop

\section{Abstract}

Decree of the Minister of Administrative and Bureaucratic Reform No. 16/2009 on Functional Master and credit figures one of them, arranged that the activities of teachers should include the main elements of sustainable development professionalism, which includes: (1) self-development; (2) scientific publications; and (3) the innovative work. By paying attention to the elements of activities that must be met by the teacher at the top, where teachers are required to be able to produce the scientific work (innovative) and publish it, then the Executive Team PKM intended to determine the ability of science teachers SMP in Jombang in preparing the research proposal action class. Method in PKM activity include: providing information about Classroom Action Research (CAR) and CAR proposal development workshop

Keywords: Proposal, Classroom Action Research (CAR), workshop

\section{PENDAHULUAN}

Pada Lampiran Peraturan Menteri Pendidikan Kebudayaan Republik Indonesia Nomor 4 Tahun 2014, tentang penyesuaian penetapan angka kredit guru PNS dan guru bukan PNS dijelaskan bahwa angka kredit unsur dan subunsur kegiatan guru berdasarkan Keputusan Menteri Pendayagunaan Aparatur Negara dan Reformasi Birokrasi Nomor 16/2009 tentang Jabatan Fungsional Guru dan Angka kreditnya, diatur bahwa kegiatan guru harus meliputi unsur utama dan unsur penunjang. Pada unsur utama terdapat: (a) Pendidikan; (b) Pembelajaran/bimbingan dan tugas tertentu/tambahan; dan (c) Pengembangan keprofesian berkelanjutan, yang meliputi: (1) pengembangan diri; (2) publikasi ilmiah; dan (3) karya inovatif. Pada unsur penunjang terdapat: (a) Kesesuaian ljazah dan (b) Pendukung tugas guru.

Dengan memperhatikan unsur-unsur kegiatan yang harus dipenuhi oleh guru di atas, khususnya terkait pengembangan keprofesian berkelanjutan, di mana guru dituntut untuk bisa menghasilkan karya ilmiah (inovatif) dan mempublikasikannya, maka Tim Pelaksana PKM bermaksud untuk melaksanakan Pendampingan Penyusunan Proposal Penelitian Tindakan Kelas (PTK) bagi Guru-guru SMP Kabupaten Jombang.

Undang-undang Nomor 12 Tahun 2012 tentang Pendidikan Tinggi Pasal 45 menegaskan bahwa penelitian di perguruan tinggi diarahkan untuk mengembangkan ilmu pengetahuan dan teknologi, serta meningkatkan kesejahteraan masyarakat dan daya saing bangsa. Pasal tersebut juga menegaskan bahwa pengabdian kepada masyarakat (PKM) merupakan kegiatan sivitas akademika dalam mengamalkan dan membudayakan ilmu pengetahuan dan teknologi untuk memajukan kesejahteraan umum dan mencerdaskan kehidupan bangsa. Oleh karena itu PKM merupakan kegiatan yang wajib dilaksanakan oleh dosen minimal sekali dalam 1 tahun. Kegiatan PKM 
akan mendapat nilai angka kredit yang dipergunakan untuk memenuhi persyaratan kenaikan pangkat dosen.

Pada tahun 2015 ini, tim dosen Unesa Surabaya Program Studi Pendidikan IPA bermaksud mengadakan PKM bagi guru-guru SMP di Kabupaten Jombang. Menurut informasi secara lisan dari Kepala Dinas Pendidikan Kabupaten Jombang bahwa guruguru SMP khususnya yang mengajar IPA masih banyak yang belum bisa mengadakan penelitian tindakan kelas dan menyusun laporannya. Buktinya masih banyak guru yang tertunda kenaikan pangkatnya, karena tidak membuat atau melakukan kesalahan dalam penyusunan karya ilmiah khususnya PTK. Permasalahan yang bisa diangkat dalam PKM ini adalah bagaimana kemampuan guru-guru IPA SMP Kabupaten Jombang, dalam menyusun proposal PTK.

\section{METODE PELAKSANAAN}

Metode pelaksanaan PKM ini menggunakan metode pendampingan yang mencakup langkah-langkah sebagai berikut.

1. Memberi informasi tentang PTK.

2. Workshop penyusunan proposal PTK.

Tabel 1. Kegiatan Pelaksanaan PKM

\begin{tabular}{|c|c|c|}
\hline Kegiatan & Aktivitas Tim Pelaksana PKM & $\begin{array}{l}\text { Aktivitas Guru-guru } \\
\text { IPA }\end{array}$ \\
\hline $\begin{array}{l}1 . \\
\text { emberi Informasi tentang: } \\
\text { a. } \\
\text { ara melaksanakan PTK. } \\
\text { b. } \\
\text { ara menyusun laporan } \\
\text { PTK. }\end{array}$ & $\begin{array}{l}\text { Memberikan informasi tentang } \\
\text { cara melaksanakan PTK dan } \\
\text { cara menyusun laporan PTK. }\end{array}$ & $\begin{array}{l}\text { Memperhatikan, } \\
\text { mendengarkan dan } \\
\text { menanyakan hal-hal } \\
\text { yang belum diketahui } \\
\text { atau dipahami. }\end{array}$ \\
\hline $\begin{array}{l}2 . \\
\text { orkshop penyusunan } \\
\text { proposal PTK. }\end{array}$ & $\begin{array}{l}\text { 1. Mendampingi guru-guru IPA } \\
\text { dalam menyusun proposal } \\
\text { PTK berdasarkan masalah } \\
\text { pada kegiatan pembelajaran. } \\
\text { 2. Mendiskusikan proposal PTK } \\
\text { yang telah disusun guru-guru } \\
\text { IPA. }\end{array}$ & $\begin{array}{l}\text { 1. Menyusun proposal } \\
\text { PTK berdasarkan } \\
\text { masalah pada } \\
\text { kegiatan } \\
\text { pembelajaran. } \\
\text { 2. Mendiskusikan } \\
\text { proposal PTK yang } \\
\text { telah disusun. }\end{array}$ \\
\hline
\end{tabular}

\section{HASIL DAN PEMBAHASAN}

Hasil kemampuan guru-guru IPA dalam menyusun proposal PTK yang meliputi judul, pendahuluan, perumusan dan pemecahan masalah, tujuan, manfaat, kajian pustaka, metode penelitian, jadwal penelitian, daftar pustaka, dan penggunaan bahasa, diperoleh skor masing-masing adalah sebagai berikut.

Tabel 2. Penilaian Proposal PTK

\begin{tabular}{lcllcc}
\hline Nama Guru IPA & Asal sekolah & \multicolumn{1}{c}{ Judul } & Skor \\
\hline Dwi & SMPN 1 Mojoagung & Penerapan Media Pembelajaran PheT & 66 \\
Prapminingrum, & & Dengan Pendekatan CTL Untuk & \\
S.Si. & & Meningkatkan Hasil Belajar Pada Materi & \\
& & Listrik Dinamis Siswa Kelas IX-D SMP & \\
& & Negeri 1 Mojoagung. & & \\
\hline Arfa'atut Tolifah & SMPN & Upaya Meningkatkan Hasil Belajar Siswa & 72 \\
& Bandarkedungmulyo & Pada Materi Listrik Dinamis Dengan & \\
& & Penerapan Pendekatan CTL Yang & \\
& & Menggunakan Media PheT Siswa Kelas 9- & \\
& & 1 SMP Negeri Bandarkedungmulyo & \\
& & Jombang. & & & \\
\hline Sri Lestari Utami & SMPN 1 Ploso & Peningkatan Ketrampilan Proses Sains & 73 \\
Ery Kustini & SMPN 1 Plandaan & (KPS) melalui Metode Direct Instruction & \\
\hline & & & & &
\end{tabular}




\begin{tabular}{|c|c|c|c|}
\hline Nama Guru IPA & Asal sekolah & Judul & Skor \\
\hline & & $\begin{array}{l}\text { (DI) dan Tutor Sebaya Siswa kelas IX di } \\
\text { SMP Negeri } 1 \text { Ploso }\end{array}$ & \\
\hline $\begin{array}{l}\text { Drs. Bambang } \\
\text { Djoko Soeparno, } \\
\text { M.Pd. }\end{array}$ & SMPN 1 Mojoagung & $\begin{array}{lcr}\text { Penerapan } & \text { Pembelajaran } & \text { Inquiry } \\
\text { Terstruktur } & \text { Untuk } \quad \text { Meningkatkan } \\
\text { Keterampilan Proses Sains Pada Siswa } \\
\text { Kelas 7A SMP Negeri } 1 \text { Mojoagung }\end{array}$ & 78 \\
\hline $\begin{array}{l}\text { Dra. Wiwik Heri } \\
\text { Setiowati. }\end{array}$ & SMPN 1 Ngoro & $\begin{array}{l}\text { Penerapan Perpaduan } \\
\text { Pembelajaran Jigsaw dan NHT } \\
\text { Untuk Meningkatkan Hasil Belajar } \\
\text { Siswa Kelas VIII A Pada Materi Tahapan } \\
\text { Perkembangan Manusia Di SMPN 1 Ngoro }\end{array}$ & 65 \\
\hline $\begin{array}{l}\text { Wiwik Ernawati, } \\
\text { S.Pd. } \\
\text { Sri Saraswati }\end{array}$ & $\begin{array}{l}\text { SMPN } 1 \text { Mojowarno } \\
\text { SMPN } 2 \text { Mojowarno }\end{array}$ & $\begin{array}{l}\text { Penerapan Model Direct Instruction } \\
\text { Untuk Meningkatkan } \quad \text { Keterampilan } \\
\text { Mengukur Luas Bidang Tak Beraturan } \\
\text { Siswa Kelas VII G SMPN } 1 \text { Mojowarno } \\
\text { Tahun Pelajaran 2015/2016 }\end{array}$ & 91 \\
\hline $\begin{array}{l}\text { Lily Limarohmi, } \\
\text { S.Pd. }\end{array}$ & SMPN 1 Jombang & $\begin{array}{llr}\text { Penerapan Pembelajaran Langsung } \\
\text { Berbantuan Media Interaktif Untuk } \\
\text { Meningkatkan Keterampilan Penggunaan } \\
\text { Mikrometer Dan Jangka Sorong Pada } \\
\text { Siswa Kelas VII-C SMP Negeri } 1 \\
\text { Jombang Tahun Pelajaran 2015- 2016 }\end{array}$ & 80 \\
\hline Didik Suryanto & SMPN 2 Megaluh & $\begin{array}{lrr}\text { Penerapan Diskusi } & \text { Terorganisir } & \text { Dalam } \\
\text { Pembelajaran } & \text { Kooperatif } & \text { Untuk } \\
\text { Meningkatkan } & \text { Penguasaan } & \text { Konsep } \\
\text { Reproduksi Pada Manusia Siswa Kelas IX } \\
\text { A SMP Negeri 2 Megaluh }\end{array}$ & 72 \\
\hline $\begin{array}{l}\text { Sofa Ismaida, } \\
\text { S.Pd. }\end{array}$ & SMPN 1 Diwek & $\begin{array}{l}\text { Penerapan Pembelajaran Kooperatif Tipe } \\
\text { TPS (Think-Pair-Share) Untuk } \\
\text { Meningkatkan Hasil Belajar IPA } \\
\text { Kelas VII B SMPN } 1 \text { Diwek }\end{array}$ & 88 \\
\hline $\begin{array}{l}\text { Lilik Muniroh, } \\
\text { S.Pd. }\end{array}$ & SMPN 2 Tembelang & $\begin{array}{l}\text { Peningkatkan Hasil Belajar Siswa Pada } \\
\text { Materi Pewarisan Sifat dan Penerapannya } \\
\text { Melalui Implementasi Tipe STAD Di Kelas } \\
\text { 9F SMP } 2 \text { Tembelang }\end{array}$ & 61 \\
\hline Churiati Kusna & SMPN 2 Perak & $\begin{array}{l}\text { Meningkatkan Motivasi Belajar Dengan } \\
\text { Menggunakan Metode Eksperimen Pada } \\
\text { Sistim Pencernaan Pada Siswa Kelas } 8 \\
\text { Tahun Pelajaran } 2014 \text { / } 2015\end{array}$ & 29 \\
\hline $\begin{array}{l}\text { Sri Amaliya, } \\
\text { S.Pd. }\end{array}$ & SMPN 3 Peterongan & $\begin{array}{l}\text { Penerapan Pemodelan } \\
\text { Meningkatkan Prestasi Belajar Siswa IX C } \\
\text { SMPN } 3 \text { Peterongan pada Sub Materi } \\
\text { Elektron }\end{array}$ & 60 \\
\hline $\begin{array}{l}\text { Mu'tamarotin, } \\
\text { S.Pd }\end{array}$ & SMPN 1 Sumobito & $\begin{array}{l}\text { Upaya Peningkatan Hasil Belajar dengan } \\
\text { Pendekatan Pembelajaran Contekstual } \\
\text { Teaching and Learning (CTL) Multi Model } \\
\text { Pada Pokok Bahasan Hukum Kirchoff di } \\
\text { Kelas IX di SMP Negeri } 1 \text { Sumobito } \\
\text { Jombang. }\end{array}$ & 69 \\
\hline Agus Suherman & SMP N 3 Mojoagung & $\begin{array}{l}\text { Peningkatan Hasil Belajar Tentang Sistem } \\
\text { Gerak Pada manusia Menggunakan Model } \\
\text { Kooperatif Tipe Think Pair Share Pada } \\
\text { Kelas VIII Di SMP Negeri } 3 \text { Mojoagung } \\
\text { Tahun Pelajaran } 2015 / 2016\end{array}$ & 62 \\
\hline
\end{tabular}


Proposal PTK yang dihasilkan memenuhi standar keberhasilan yang ditetapkan, yaitu skor $\geq 75$ sebanyak 4 dari 14 proposal PTK. Hal ini disebabkan sebagian peserta tidak melengkapi aspek-aspek yang harus terdapat pada proposal. Pada aspek judul yaitu menggambarkan masalah yang diteliti, tindakan untuk mengatasi masalah, hasil yang diharapkan dan tempat penelitian, peserta sudah tepat dalam memberi judul proposal PTK.

Pada aspek pendahuluan yaitu keberadaan masalah nyata dan jelas, penyebab masalah jelas, dan masalah serta penyebabnya diidentifikasi secara jelas, sebagian peserta mendapatkan skor kurang dalam mengidentifikasi penyebab masalah. Aspek perumusan dan pemecahan masalah yaitu rumusan masalah sesuai dengan masalah dalam bentuk rumusan masalah PTK dan bentuk tindakan untuk memecahkan masalah, sebagian peserta kurang sesuai dalam menuliskan rumusan masalah.

Aspek tujuan yaitu sesuai dengan rumusan masalah, karena sebagian peserta dalam menuliskan rumusan masalah kurang sesuai, maka tujuan juga kurang sesuai dengan rumusan masalah. Aspek manfaat yaitu jelas manfaat penelitiannya, peserta sudah sesuai dengan penelitiannya. Aspek kajian pustaka yaitu relevansi antara pointpoint yang dikaji dengan permasalahan dan jelas kerangka berpikirnya, sebagian peserta menuliskan permasalahan kurang relevan.

Aspek metode penelitian yaitu jelas subjek, tempat, dan waktu penelitian, ada perencanaan rinci langkah-langkah PTK dan kriteria keberhasilan, sebagian peserta tidak menuliskan langkah-langkah PTK dan siklus PTK.

Aspek jadwal penelitian yaitu jadwal penelitian dalam bentuk Gantt Chart, sebagian peserta tidak menuliskan jadwal penelitian. Kemudian, aspek daftar pustaka yaitu penulisan daftar pustaka sesuai ketentuan, sebagian peserta tidak menuliskan daftar pustaka. Kekurangan dan kelemahan kemampuan peserta dalam menyusun proposal PTKnya masing-masing disebabkan semata-mata keterbatasan waktu.

\section{SIMPULAN DAN SARAN}

Proposal PTK yang dihasilkan oleh guruguru IPA se kabupaten Jombang telah memenuhi standar keberhasilan yang ditetapkan, yaitu skor $\geq 75$ sebanyak 4 dari 14 proposal PTK dan sisanya mendapatkan skor $\leq 75$, hal ini disebabkan sebagian peserta tidak melengkapi aspek-aspek yang harus dipersyaratkan ada pada proposal.

Saran yang diusulkan, agar proses pendampingan penyusunan proposal PTK ini lebih efektif diberikan waktu yang agak lama untuk menghasilkan proposal yang sesuai dengan aspek-aspek yang ada dalam proposal PTK.

\section{DAFTAR PUSTAKA}

Tim Unesa. 2014. Materi Pendidikan dan Latihan Profesi Guru (PLPG): Penelitian Tindakan Kelas. Jakarta: Direktorat PSMP.

Hullet, Elwyn C. 2008. Action Research in the Classroom. USA: Eastern New Mexico University Printing. 